\title{
Ground Water Elevation Monitoring at THE URANIUM Mill Tallings Remedial Action Salt Lake City, Utah, Vitro Processing Site
}

April 1995

DISTRIBUTION QF THIS DOCUUMENT IS UNLIMITED WW' 


\section{DISCLAIMER}

Portions of this document may be illegible in electronic image products. Images are produced from the best available original document. 
This report has been reproduced from the best available copy. Available in paper copy and microfiche

Number of pages in this report:

DOE and DOE contractors can obtain copies of this report from:

Office of Scientific and Technical Information

P.0. Box 62

Oak Ridge, TN 37831

(615) 576-8401

This report is publicly available from:

National Technical Information Service

Department of Commerce

5285 Port Royal Road

Springfield, VA 22161

(703) 487-4650 
REV. 0

\title{
GROUND WATER ELEVATION MONITORING AT THE URANIUM MILL TAILINGS REMEDIAL ACTION SALT LAKE CITY, UTAH, VITRO PROCESSING SITE
}

\section{April 1995}

\author{
Prepared for \\ U.S. Department of Energy \\ UMTRA Project \\ Albuquerque, New Mexico \\ Prepared by \\ Jacobs Engineering Group Inc. \\ Albuquerque, New Mexico
}

\section{DISCLAIMER}

This report was prepared as an account of work sponsored by an agency of the United States Government. Neither the United States Government nor any agency thereof, nor any of their employees, makes any warranty, express or implied, or assumes any legal liability or responsibility for the accuracy, completeness, or usefulness of any information, apparatus, product, or process disclosed, or represents that its use would not infringe privately owned rights. Reference herein to any specific commercial product, process, or service by trade name, trademark, manufacturer, or otherwise does not necessarily constitute or imply its endorsement, recommendation, or favoring by the United States Government or any agency thereof. The views and opinions of authors expressed herein do not necessarily state or reflect those of the United States Government or any agency thereof. 


\section{TABLE OF CONTENTS}

Section

INTRODUCTION 1

Ground water level monitoring program ................................................ 1

Results of ground water level monitoring .................................................. 3

Conclusion: recommendations for additional monitoring ............................... 3

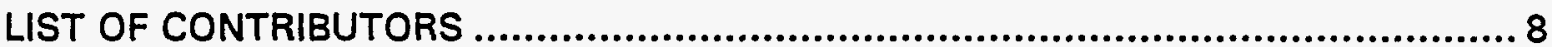

\section{LIST OF FIGURES}

Figure

1 Locations of wells monitored for ground water levels, irrigated driving range, and proposed golf course, Salt Lake City, Utah, Vitro processing site.

2 Monthly or bimonthy ground water levels in the unconfined aquifer, Salt Lake City Utah, Vitro processing site .............................................. 4

3 Daily ground evaluations, well 131, Vitro processing site.............................. 5

\section{LIST OF TABLES}

Table

1 Ground water elevations in the unconfined aquifer, Salt Lake City, Utah, Vitro processing site

\section{LIST OF ACRONYMS}

\section{Acronym Definition}

CVWRF

UMTRA

Central Valley Water Reclamation Facility

Uranium Mill Tailings Remedial Action 


\section{INTRODUCTION}

In February 1994, a ground water level monitoring program was begun at the Vitro processing site. The purpose of the program was to evaluate how irrigating the new golf driving range affected ground water elevations in the unconfined aquifer. The program also evaluated potential impacts of a 9-hole golf course planned as an expansion of the driving range. The planned golf course expansion would increase the area to be irrigated and, thus, the water that could infiltrate the processing site soil to recharge the unconfined aquifer. Increased water levels in the aquifer could alter the ground water flow regime; contaminants in ground water could migrate off the site or could discharge to bodies of surface water in the area. The potential effects of expanding the golf course have been evaluated, and a report is being prepared.

Water level data obtained during this monitoring program indicate that minor seasonal mounding may be occurring in response to irrigation of the driving range. However, the effects of irrigation appear small in comparison to the effects of precipitation. There are no monitor wells in the area that irrigation would affect most (Figure 1); that data limitation makes interpretations of water levels and the possibility of ground water mounding uncertain. Limitations of available data are discussed in the conclusion.

Another activity at the processing site that could affect contaminant migration is dewatering of the unconfined aquifer on the Central Valley Water Reclamation Facility (CVWRF) property, where the sewage treatment plant is being expanded. Dewatering the aquifer beneath the plant is likely to change ground water levels at the Vitro processing site, possibly increasing ground water movement to the north.

The current monitoring program's scope should be increased to enable an adequate assessment of any potential impacts that could result from the proposed golf course expansion and the dewatering activities. Continuous water level measurements are necessary in more of the existing monitor wells and piezometers using additional data loggers. Elevations of surface waters and topographically low areas on and near the site should also be measured.

\section{GROUND WATER LEVEL MONITORING PROGRAM}

Since February 1994, ground water levels in the shallow unconfined aquifer have been measured in monitor wells 130,131, 132, 133, 134, and 135. A CVWRF employee has been measuring ground water levels approximately once a month in these wells. In July 1994, a data logger was installed in monitor well 131 to record water levels at hourly intervals. On 1 March 1995, the Uranium Mill Tailings Remedial Action (UMTRA) site hydrogeologist and geochemist visited the site to obtain ground and surface water level data, water usage data for the driving range, and to investigate current site conditions. Monthly rainfall data for 1994 was obtained from the U.S. Weather Service station at the Salt Lake City airport. 


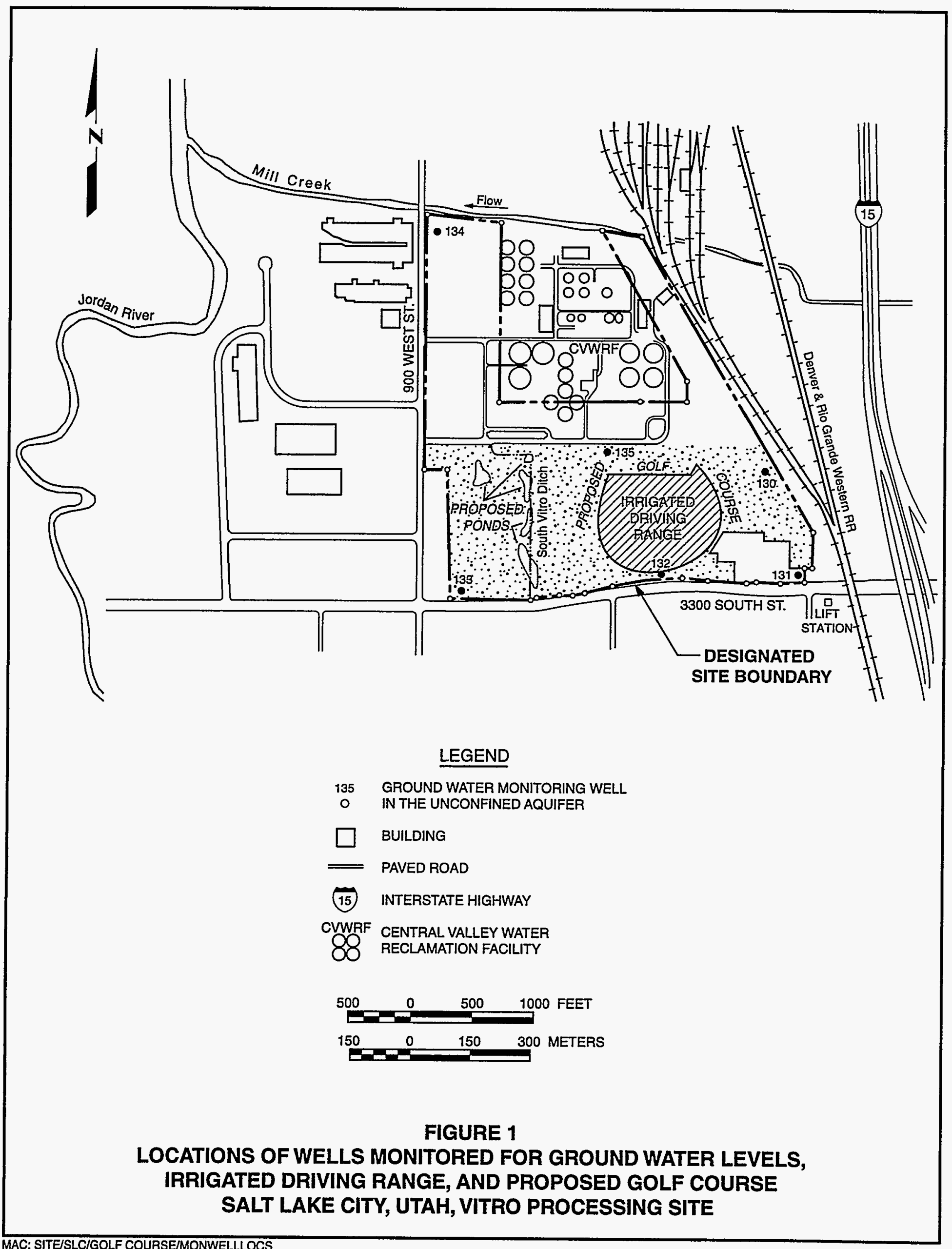




\section{RESULTS OF GROUND WATER LEVEL MONITORING}

Figure 2 shows hydrographs for all the monitor wells from 10 February 1994 to 1 March 1995. Figure 3 shows a data logger hydrograph for monitor well 131.

Data collected from the monitor wells in 1994 indicate that water levels in the unconfined aquifer are affected primarily by precipitation. Water levels declined to their lowest levels in the summer, the period of low rainfall, and increased to their highest levels in the late fall and winter months, the period of high rainfall and snowfall (Figures 2 and 3). Water levels in these monitor wells responded quickly to precipitation (Figure 2). One inch of monthly precipitation produces a water level rise of approximately 8 inches in the unconfined aquifer. During 1994, monthly rainfall varied from a trace in July to as much as 2.4 and 2.9 inches in October and November, respectively. During the same period, water levels in the unconfined aquifer rose as much as 32 inches (Table 1).

Irrigation apparently has much less of an effect than precipitation on water levels. Irrigation records indicate that 0.2 to 0.9 inches of water were applied to the driving range every month from May through September of 1994, for a total of approximately 3 inches of water. Assuming that the relation between irrigation and water levels is similar to the relation between water levels and precipitation, irrigation can be expected to cause water levels beneath the driving range to increase by 1.5 to 7 inches above the levels in nonirrigated areas. Water levels in monitor well 132, located on the southern edge of the irrigated area, declined by 6 to 13 inches less, respectively, than levels in wells 130 and 133 (Figure 2), which are farther from the irrigated area. The 6-to 13-inch difference in water levels is consistent with the amount of water applied during irrigation. This suggests that irrigation may cause the seasonal development of a localized ground water mound, which could lead to a change in ground water flow directions and to the possible movement of contaminated ground water off the site.

\section{CONCLUSION: RECOMMENDATIONS FOR ADDITIONAL MONITORING}

The low density of monitor wells and piezometers limits our understanding of ground water flow conditions at the site. Little of the area proposed for the golf course expansion is monitored by wells or piezometers; additional monitor wells and/or piezometers are needed to collect ground water quality and level data in areas where no data are presently available. With these data, water levels in the irrigated and nonirrigated areas could be compared and the effects of expanding the golf course could be better predicted.

Additional water level and chemical data near South Vitro Ditch are also needed to predict the effects of any potential ground water discharge to the proposed golf course ponds.

Additional data loggers are recommended for existing monitor wells $130,132,133,134$, and 135. The data loggers are needed to obtain data sufficient to adequately assess any potential impacts of the golf course expansion and the dewatering operations at the sewage treatment plant.

- Water levels in well 130 could be influenced by irrigation of the driving range because it is about 120 feet from the irrigated area in a cross-gradient direction. 


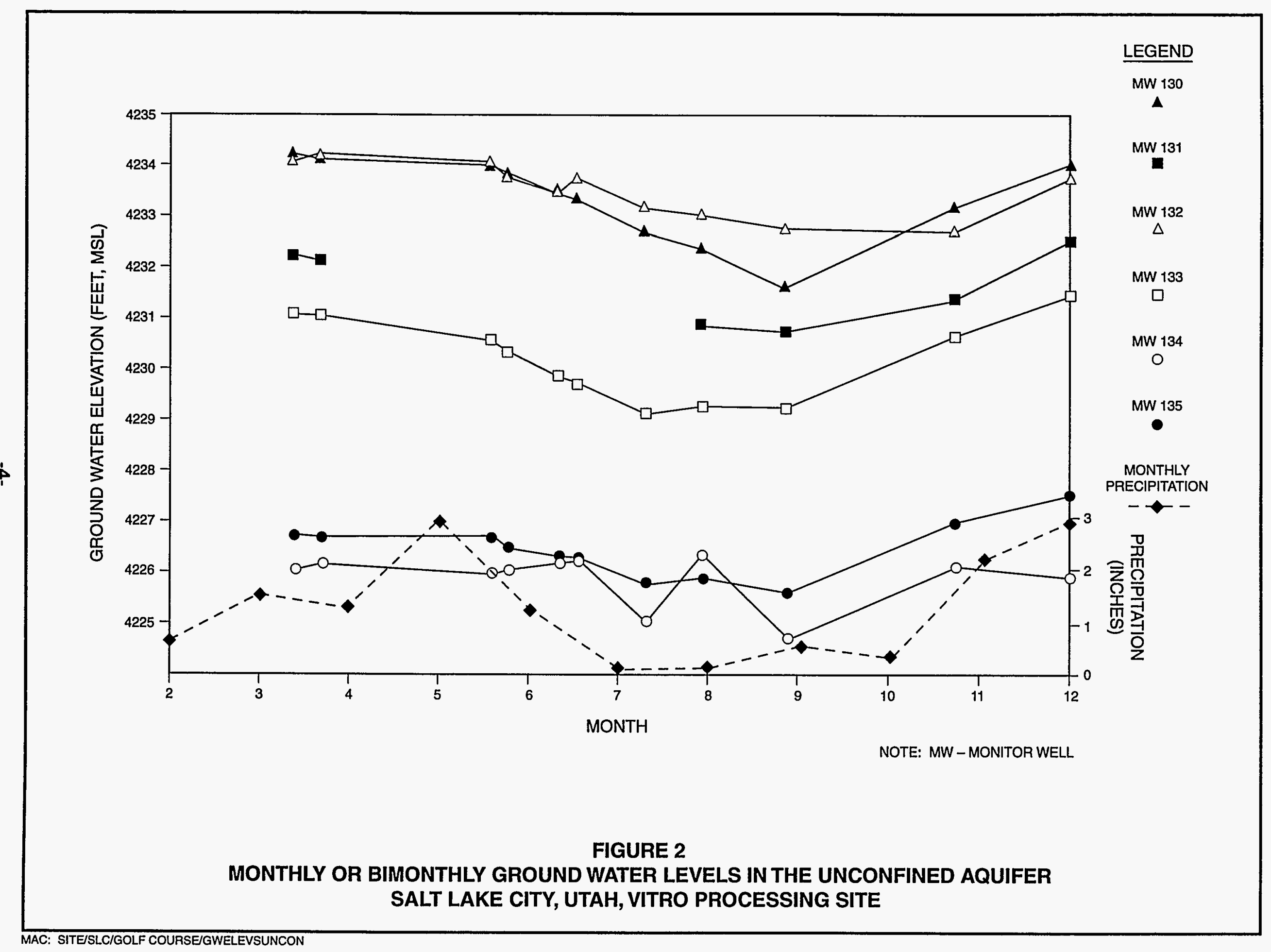




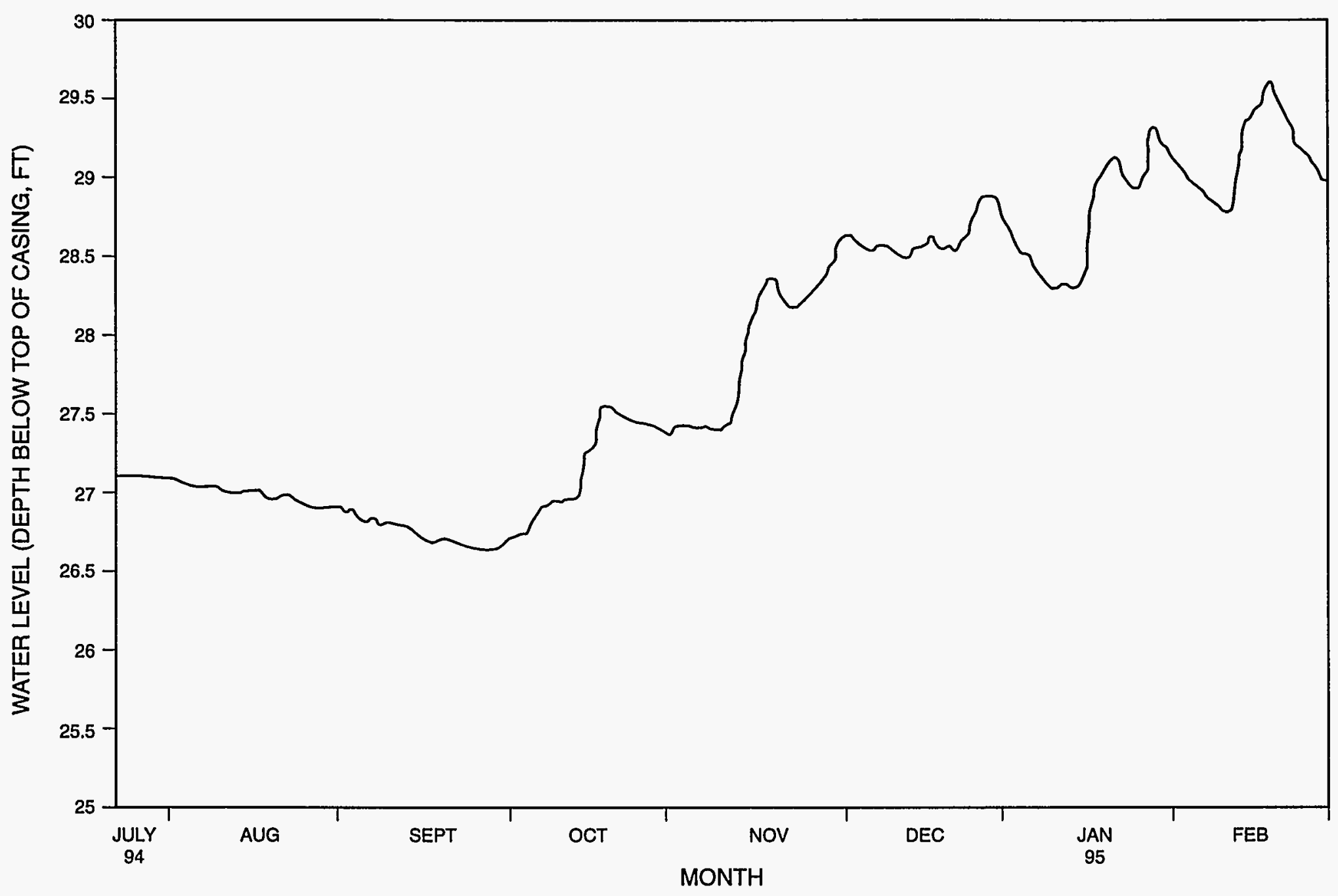

FIGURE 3

DAILY GROUND WATER LEVELS (WELL 131)

SALT LAKE CITY, UTAH, VITRO PROCESSING SITE 
Table 1 Ground water elevations in the unconfined aquifer, Salt Lake City, Utah, Vitro processing site

\begin{tabular}{|c|c|c|c|c|c|c|}
\hline & \multicolumn{6}{|c|}{ Monitor Well ID } \\
\hline & SLC01-130 & SLC01-131 & SLC01-132 & SLC01-133 & SLC01-134 & SLC01-135 \\
\hline & \multicolumn{6}{|c|}{ Surface Elevation (feet above MSL) } \\
\hline & 4240.22 & 4240.01 & 4239.99 & 4238.83 & 4239.50 & 4236.10 \\
\hline Date (1994) & \multicolumn{6}{|c|}{ Water Level Elevations (in feet above MSL) } \\
\hline March 11 & 4234.27 & 4232.26 & 4234.12 & 4231.13 & 4226.10 & 4226.75 \\
\hline March 18 & 4234.17 & 4232.16 & 4234.22 & 4231.08 & 4226.20 & 4226.70 \\
\hline May 17 & 4234.00 & NM & 4234.09 & 4230.58 & 4226.00 & 4226.70 \\
\hline May 23 & 4233.87 & NM & 4233.79 & 4230.33 & 4226.05 & 4226.50 \\
\hline June 9 & 4233.52 & NM & 4233.49 & 4229.88 & 4226.20 & 4226.35 \\
\hline June 15 & 4233.37 & NM & 4233.77 & 4229.73 & 4226.23 & 4226.30 \\
\hline July 8 & 4232.72 & NM & 4233.19 & 4229.13 & 4225.05 & 4225.80 \\
\hline July 28 & 4232.37 & 4230.9 & 4233.04 & 4229.28 & 4226.35 & 4225.90 \\
\hline August 26 & 4231.62 & 4230.75 & 4232.74 & 4229.23 & 4224.70 & 4225.60 \\
\hline October 21 & 4233.17 & 4231.35 & 4232.69 & 4230.63 & 4226.10 & 4226.95 \\
\hline November 30 & 4233.98 & 4232.50 & 4233.73 & 4231.41 & 4225.88 & 4227.50 \\
\hline Maximum & 4234.27 & 4232.50 & 4234.22 & 4231.41 & 4226.35 & 4227.50 \\
\hline Minimum & 4231.62 & 4230.75 & 4232.69 & 4229.13 & 4224.70 & 4225.60 \\
\hline Range (feet) & 2.65 & 1.75 & 1.53 & 2.28 & 1.65 & 1.90 \\
\hline
\end{tabular}

Note: Water levels measured using a steel tape.

NM - not measured 
- Continuous water level measurements are necessary in monitor well 132 to determine the influence of irrigation on ground water levels beneath the driving range.

- Water levels in well 133 should show the least influence of irrigation because of its distance from the irrigated area (more than 700 feet in a cross-gradient direction).

- Well 134 should be monitored continuously for water levels because it reflects flow and water levels in Mill Creek, which is a major influence on discharge from the unconfined aquifer.

- Monitoring of well 135 will provide water level data from the center of the site. Well 135 is also closest to the CVWRF dewatering well.

These additional data loggers should be installed as soon as possible so that data can begin to be collected before irrigation starts in the late spring. Additional water level measurements are necessary in monitor well 131 to maintain a continuous record from July 1994 to the end of the irrigation season in the fall of 1995.

Daily rainfall data will also be obtained from the U.S. Weather Service station at the Salt Lake City airport. Rainfall data will be compared to water level data from the data loggers. Surface water elevations and topographically low areas on and near the site must be surveyed to determine whether there is any potential for discharge of contaminated ground water to the surface. 


\section{LIST OF CONTRIBUTORS}

The following individuals contributed to the preparation of this report.

\begin{tabular}{ll}
\hline Name & Contribution \\
\hline B. Smith & Document coordinator \\
B. Smith, T. Jackson & Primary authors \\
S. Wright, A. Holm & Document review \\
V. Beck & Editing \\
L. Sanchez & Text processing \\
\hline
\end{tabular}

